\title{
Land conversion to the poor people in the perspective of utilitarianism theory by bentham
}

\author{
Yusrizal $^{*}$ and Muhammad Yamin Lubis \\ Law Program, University of Sumatera Utara, Indonesia
}

\begin{abstract}
The politics of Indonesia's national land law is based on the principle of fulfilling the constitutional rights of every citizen of the land. The land according to Indonesian positive law is used for the general welfare of Indonesian People. In 2001, with the issuance of MPR RI Decree No.IX / MPR-RI / 2001 concerning Agrarian Reform and Natural Resource Management is the momentum of the agrarian reform program. Agrarian reform is implemented gradually by allocating land for the poor. The problem is: the distribution of the land is not right on target, the existence of a land mafia, bribery of the National Land Agency and the annexation of community land by the investor. Karo Regency became one of the areas which received land allocation from conversion forest.This research method is empirical legal research. This research uses primary data. This research use legal benefit theory (utilitarian) by Jeremy Bentham. Based on legal benefit theory, that agrarian reform by giving land conversion to the poor is an alternative effort of government to give decent living and fulfillment of constitutional rights of Indonesian citizen and eradicate poverty.
\end{abstract}

\section{Introduction}

Land is a very basic necessity of human life. Humans live and perform activities on the land, so that every time humans are always associated with the land, can be said almost all human life activities either directly or indirectly always need the land. Even after death humans still need the land as a burial place. Once the importance of the land for human life, then everyone will always try to own and control the land.

Due to the increasing need of people to own the land, efforts are needed to optimize the use or utilization of the land in accordance with its ability and attention to the environment. It is necessary to have a land use planning, land use arrangement, land rights management, provision of data or land registration maps with mapping and land registration measurement activities. ${ }^{[1]}$

Land has a great role in the dynamics of development, then in the 1945 Constitution Article 33 paragraph (3) mentioned that the earth, water and natural resources contained therein are controlled by the state and used for the greatest prosperity of the people. The provisions on the land can also be seen in Act Number 5 of 1960 concerning the Basic Regulations of Agrarian Principles or what we usually call the Agrarian Act.

*Corresponding author: yusrizal_legal@hotmail.com 
Talking about the definition of the land we will revolve around Act Number 5 of 1960 , but in the provisions of the legislation is not mentioned in detail about the definition of the land. Act Number 5 of 1960 on Article 1 only mentioned about earth, water and space is an inseparable unity which is also known as a concept of understanding of the definition of the Archipelagic Insight. According to A.P. Parlindungan, land means "Surface of the Earth". ${ }^{[2]}$

The surface of the earth includes water, land and space as well as what is contained therein. This is described because the land as an object given the right of ownership or ownership over it, is not limited only to the definition of the land in the true sense, but also includes visible water (eg ponds above the ground) and water in the soil (such as water obtained from within the soil through a well) is owned by a person holding the rights to the land above the surface of the earth.

The definition of "control" can be used in a physical sense, also in a juridical sense. Juridical definition are based on rights protected by law and generally authorize the rightholders to physically occupy the land in custody. The definition of control is used in the civil sense In the 1945 Constitution and Agrarian Act the definition of "controlled" is used in a public sense, as defined in Article 2 of the Agrarian Act. the definition consist of land rights such as property rights (Article 20), the right to use and the right to collateral for land called mortgages (Articles 23, 33, 39 and 51). While the right to control the state that the public law is the right to control the state that covers all the land without any exceptions.

The legal relationship between the State and the land gives birth to the right to control the land rights by the State. The relationship between indigenous and tribal peoples with their communal lands gave birth to customary rights and a combination of individuals and lands gave birth an individual rights to the land. Ideally, the relationship of the three rights (the right to control the land by the State, customary rights, and individual rights to the land) is harmoniously and equitably aligned, meaning that the three rights are equal and strength and not mutually harmful. However, legislation in Indonesia gives great power and unclear limits to the State to control all the land in the territory of Indonesia.

One of the fundamental perspectives of land management is that all land rights have social functions (Article 6 Agrarian Act), the management of land is in principle a Government affair. Therefore, the social function of land rights can be set forth in the form of policy, regulation, control and supervision, and service. In carrying out these social missions the government considers the availability of land, to be able to meet the needs of stakeholders, justice for all the people, legal certainty and protection for holders of land rights, and sustainability in services, availability and ecosystems. ${ }^{[3]}$

With the existence of the National Land Law is expected to create legal certainty in Indonesia. To achieve this objective, the government implemented it with the provision of written legal instruments in the form of other regulations in the field of national land law which support legal certainty and implementing the law enforcement through the existing regulatory instruments in the form of effective land registration.

According to Article 9 of Government Regulation Number 24 of 1997 concerning Land Registry, which can be the object of land registration are:

1. Land parcels having the status of hak milik (right of ownership), hak guna usaha (right to cultivate), hak guna bangunan (right of use building), and hak pakai (right of use);

2. Land having the status of hak pengelolaan (right of management);

3. Wakaf land (edified land/land donated for religious purposes);

4. An apartment ownership right;

5. Security title;

6. State land.

In reality there is still the right of eigendom, opstal rights, erfpacht rights and indigenous rights subject to customary law which have no written evidence, which local residents have 
often called customary lands such as communal land, customary land, Yasan land, gogolan Land, etc.Under the terms of Article 9 above, it is clear that land derived from western rights can not be registered. If these lands can not be registered, this policy will disadvantage the landowners, because they will certainly lose their rights. It is therefore necessary to have a way for this soil to be registered, then the way it can be done is to convert the land from the western right. With the conversion of land from the western rights, it is hoped that the people will not lose their rights because after being converted the right will be able to be registered ${ }^{[4]}$

Conversion of land rights is one of the instruments to fulfill the principle of legal unification through Act Number 5 of 1960. The Regulation of the Minister of Land and Agrarian Affairs Number 2 of 1962 regulates the provisions on affirmation of conversion and registration of ex-rights of Indonesia over land normatively. The conversion rule is the implementation of transitional provisions of Act Number 5 of 1960 . The purpose of registration of land conversion to provide legal certainty, legal protection to holders of land rights or produce a Certificate of Right which is valid as a powerful evidentiary.[5]

\section{Formulation of the Problem}

This study examines the implementation of land conversion based on the perspective of Utiliarism to create a welfare state in Indonesia.

\section{Research Method}

According to Hutchinson, legal research is placed in the Applied Research category, and differentiates legal research into four types: ${ }^{[6]}$

a) Doctrinal research; research which provides a systematic esposition of the rules governing a particular legal category, analyses the relationship between rules, explain areas of dificulty and, perhaps, predits future development.

b) Reform-Oriented Research: Research which intensively evaluates the adequacy of exiting rules and which recommends changes to any rules found wanting

c) Theretical Research: research which fosters a more complete understanding of the conceptual bases of legal principles and of combined effects of a range of rules and procedures that touch on a particular area of activity.

d) Fundamental research: Research designed to secure a deeper understanding of law as a social phenemonen, including research on the historical, philosophical, linguistic, economic, social or political implication.

This research uses normative legal research with the regulation approach and field research. The analytical method used is prescriptive by placing secondary data sources as sources of legal material comprising primary legal materials, secondary legal materials and tertiary legal materials.

\section{Literature Review}

Nature has placed mankind under the governance of twosovereign masters, pain and pleasure. They alone point out what we ought to do and determine what we shall do; the standard of right and wrong, and the chain of causes andeffects, are both fastened to their throne. They govern us in all we do, all we say, all we think; every effort we can make to throw off our subjection to pain and pleasure will only serve to demonstrate and confirm it. A man may claim to reject their rule but in reality he will remain subject to it. The principle of utility: ${ }^{[7]}$ 
Recognises this subjection, and makes it the basis of a system that aims to have the edifice of happiness built by the hands of reason and of law. Systems that try to question it deal in sounds instead of sense, in caprice instead of reason, in darkness instead of light. But enough of metaphor and declamation! It is not by such means that moral science is to be improved.

The principle of utility is the foundation of the present work, so I should start by giving an explicit and determinatethe principle that approves or disapproves of every action according to the tendency it appears to have to increase or lessen i.e. to promote or oppose the happiness of the person or group whose interest is in question. I say 'of every action', not only of private individuals but also of governments.

By 'utility' is meant the property of something whereby it tends to produce benefit, advantage, pleasure, good, or happiness (all equivalent in the present case) or (this being the same thing) to prevent the happening of mischief, pain, evil, or unhappiness to the party whose interest is considered. If that party is the community in general, then the happiness of the community; if it's a particular individual, then the happiness of that individual.

'The interest of the community' is one of the most general expressions in the terminology of morals; no wonder its meaning is often lost! When it has a meaning, it is this. The community is a fictitious body composed of the individuals who are thought of as being as it were its members. Then what is the interest of the community? It is the sum of the interests of the members who compose it.

It is pointless to talk of the interest of the community without understanding what the interest of the individual is. A thing is said to 'promote the interest' (or be 'for the interest') of an individual when it tends to increase the sum total of his pleasures or (the same thing) to lessen the sum total of his pains.

An action then may be said to conform to the principle of utility. . . .when its tendency to increase the happiness of the community is greater than any tendency it has to lessenit. And the same holds for measures of government, which are merely one kind of action performed by one or more particular persons.

When someone thinks that an action (especially a measure of government) conforms to the principle of utility, he may find it convenient for purposes of discourse to imagine a kind of law or dictate of utility and to speak of the action in question as conforming to such a law or dictate.

A man may be said to be a 'partisan' of the principle of utility when his approval or disapproval of any action (or governmental measure) is fixed by and proportional to the tendency he thinks it has to increase or to lessen the community's happiness.

Of an action that conforms to the principle of utility one may always say that it ought to be done, or at least that it is not something that ought not to be done.

One may say also that it is right that it should be done; it is a right action; or at least that it is not wrong that it should be done; it is not a wrong action. When thus interpreted, the words 'ought' and 'right' and 'wrong' and others of that sort have a meaning; otherwise they have none. 
Has the rightness of this principle ever been formally contested?

The utility of human actions, Bentham said In the 1776 preface to A Fragment on Government, is their tendency to promote the common end of all such actions - happiness; and from utility in this sense, he went on, we can 'denominate a principle ... a principle that is recognized by all men'. This, he wrote four years later in the opening chapter of An Introduction to the Principles of Morals and Legislation, is the principle that is to serve as 'the foundation of that system, the object of which is to rear the fabric of felicity by the hands of reason and of law'. And he then attempted to formulate the principle itself more precisely: ${ }^{[8]}$

By the principle of utility is meant that principle which approves or disapproves of every action whatsoever, according to the tendency which it appears to have to augment or diminish the happiness of the party whose interest is in question

Happiness, moreover, is to be understood in a way already adumbrated in 1776 but now greatly elaborated in terms of the balance of pleasure over pain. However we are to interpret the celebrated opening words of the Introduction to the Principles and Bentham himself implicitly warned against attaching too much weight to 'rhetoric and declamation' we cannot ignore the fact that this is how he chose to open what he plainly envisaged as a major statement of his position

Nature has placed mankind under the governance of two sovereign masters pain and pleasure. It is for them alone to point out what we ought to do, as well as to determine what we shall do. On the one hand the standard of right and wrong, on the other the chain of causes and effects, are fastened to their throne. They govern us in all we do, in all we say, in all we think: every effort we can make to throw off our subjection, will serve but to demonstrate and confirm it ... The principle of utility recognizes this subjection.

In his discussion of the principle of utility in An Introduction to the Principles of Morals and Legislation, Bentham did not explicitly refer to paraphrase is or his other methods of exposition, yet they form the foundation upon which the whole account is constructed. In the famous opening passage he announced that the perceptions of pain and pleasure constituted the 'real source' both of the principle of utility and of human motivation. ${ }^{[9]}$

Nature has placed mankind under the governance of two sovereign masters, pain and pleasure. It is for them alone to point out what we ought to do, as well as to determine what we shall do. On the one hand the standard of right and wrong, on the other the chain of causes and effects, are fastened to their throne. They govern us in all we do, in all we say, in all we think every effort we can make to throw off our subjection, will serve but to demonstrate and confirm it. In words a man may pretend to abjure their empire but in reality he will remain subject to it all the while. The principle of utility recognize this subjection, and assumes it for the foundation of that system, the object of which is to rear the fabric of felicity by the hands of reason and of law. Systems which attempt to question it, deal in sounds instead of sense, in caprice instead of reason, in darkness instead of light.

\section{Result and Discussion}

There are 531 large scale forest concessions provided on an area of 35.8 million hectares, while on the other hand there are $60 \mathrm{HKm}, \mathrm{HD}$, and HTR licenses owned by 257486 families $(1,287,431$ inhabitants) on an area of just 646,476 hectares. The forest management in the form partnership (one model of forest management by the holder concessions by way of partnering with local communities) only reaching 11,500 hectares, while Pengelolaan Hutan Bersama Masyarakat (PHBM) Perhutani which include 5.293 Kelompok Tani Hutan (KTH), 1,200 primary cooperatives, and 5,394 villages covering only 2.1 million hectares, but not yet can provide welfare to farm households. 
According to BPN (2016) records, the total area of HGU plantations is about 15 million hectares and HGB area of 29,584 hectares. Meanwhile, the 2013 Agricultural Census by the Central Bureau of Statistics (BPS) shows that there are 2,452 large-scale agricultural enterprises in agriculture, $56 \%$ ladders only have less than 0.5 hectares of land. The number of farmers in 2013 is 31.7 million people (food crop farmers as much as 20.4 million people) who work on an area of 13.7 million hectares.

The Agrarian Reform or legally formally referred to as Agrarian Reform is the process of restructuring (ownership rearrangement) of ownership, control and use of agrarian resources (especially land). In Article 2 of the Decree of the People's Consultative Assembly of the Republic of Indonesia Number IX / MPR / 2001 it is explained that "The agrarian reform includes a continuous process with respect to the rearrangement of land ownership, use and utilization of agrarian resources, implemented in the framework of achieving legal certainty and protection and justice and prosperity for all people of Indonesia

Land Reform Plus Implementation Process, namely the arrangement of land assets for the community and structuring of public access to economic and political resources that enable the community to utilize the land properly. In the implementation of Land Reform Plus, there are two important things, namely Reform Asset and Access Reform. The Agrarian Reform aims to create an agrarian-based resources for the welfare of the people in order to organize the life of a more just society to improve the sustainability of the Indonesian national and statehood system and to promote community harmony.

The Agrarian Reform aims to create an agrarian-based resources for the welfare of the people in order to organize the life of a more just society to improve the sustainability of the Indonesian national and statehood system and to promote community harmony.

The objectives of the Agrarian Reform are to reduce poverty, create jobs, improve people's access to economic resources especially land, rearrange the inequality of ownership, use and utilization of land and agrarian resources, reduce disputes and conflicts over land and agriculture, improve and maintain quality of the environment, increasing food security and community energy.

The objective of land reform in Indonesia is to enhance the income and living standards of the tiller peasants, as a basis or prerequisite for organizing economic development towards a just and prosperous society based on Pancasila. To achieve the intended objectives is done by holding a fair share of the peasants' livelihoods in the form of land and fair share of results as well, implementing land tenure for peasants, ending the landlord system, and protecting the weak economy. Landreform programs include: ${ }^{[10]}$

a. Limitation of maximum landholding area;

b. The prohibition of land ownership in so-called "absentee" or "clasp";

c. Redistribution of the remaining lands from the maximum, the lands affected

by the "absentee" ban, the former swapraja lands and state lands;

d. Regulation of the return and redemption of pawned agricultural lands;

e. The re-arrangement of land-sharing agreements, and;

f. Determination of minimum area of agricultural land ownership, accompanied by a prohibition to engage in acts that result in the split of the ownership of agricultural lands into too small parts

Current phenomena indicates the still occurrence of land cultivation by certain parties, whereas Article 7 of the Agrarian Act regulates the prohibition of controlling the land beyond certain limits, because it is detrimental to the public interest, due to the limited supply of agricultural land, especially in densely populated areas. The scarcity of land causes the land to have a very high economic value.

Inequality in land ownership and control is increasingly apparent as a result of the uneven distribution of land, this can be seen from the symptoms, the land accumulates in the hands of certain persons or bodies. As stated by Hery Haryadi, a lecturer at the Faculty of Law 
Unika that there is a depreciation of the area of productive land. Including land tenure that only a handful of people. The biggest concern is the soaring price of the land. To minimize the aksees of the inequality, he expressed the need for awareness of the rules. Law enforcement concerning the land issue is strongly needed so that the land will not be controlled by certain people or entities. If it continues then there will be a lot of wasted land, because in housing environment not all the land is used. Whereas on the other hand a small group of people find it difficult to find land to grow crops. Presumably the ideal of Agrarian Act to realize the national land system which is devoted to the interests of the people is still far from reality.

In the seminar of Re thinking Land reform in Indonesia held by the National Land Agency with the Land Law Initiative and Rural Development Institute in Jakarta (May 2002), Deputy of Land Administration Agency of the National Land Agency, Heru Wijono stated in its development the implementation of land reform in Indonesia also stagnated, and unfinished, where the main obstacle to the implementation of land reform is the weak political will of the New Order government which is pursuing higher economic growth. This policy is not enough to give support to the weak economic community, including peasants who really need the land. Heru suggested the land policy in the framework of land reform needs to be reviewed.

In its development, the new order of agrarian politics and the reform order no longer use the concept of redistribution, but rather refers to the green revolution, transmigration and modernization. In addition, various laws of legal products of the new order which are of a legal nature no longer associate them with Agrarian Act or even contradictory to the Agrarian Act, where the pattern of control of natural resources is now shifted to state and private ownership (including foreign private).

In the future orientation of this reformation period, land reform is still needed in order to carry out development. The Government of Indonesia can follow the example of other countries that have succeeded in implementing land reform programs in their countries such as Japan, Taiwan and South Korea.

The consequences that we can still perceive today as a result of the non-implementation of land reform are: $:^{[11]}$

a. Land reform creates market or purchasing power. Without the equity of land, there is no power of purchasing power, meaning there is no market power, consequently production will not develop.

b. Peasants without land assets are synonymous with poor peasants who will not be able to create savings. Whereas agricultural savings are needed by every government, to fund agricultural development and other sectors development.

c. Without increasing the farmer's economy, the agricultural tax will remain minimal.

d. Without land reform, there would be no widespread differentiation of the division of labor in the countryside that grew out of the rural needs itself.

e. Without land reform, there will be no investment in agriculture by the peasants themselves. Instead disinvestment occurred because over time many poor peasants lost land and widespread poverty.

f. The land eventually became the object of speculation, because it could not be used productively by its peasants but was looted by the classes in the city for the benefit of speculation and non-productive investment.

As mentioned above by looking at the consequences of the non-implementation of the land reform program in the form of land conversion to economically disadvantaged communities, it is recognized that the land reform program is still needed in order to carry out development in particular to improve the livelihood of peasants. The main obstacle to the 
implementation of land conversion is the pattern of the current government's political policies that are pursuing economic growth and there is a view among bureaucrats that land conversion is a "taboo" program to be discussed, moreover to be implemented because it is considered a communist product, the concept of land for peasants is a communist concept.

Land reform through land conversion to the poor is a program of land politics policy that needs to be completed in its implementation, in order to anticipate the tendency of emergence of inequality in land ownership. What must be done is to make adjustments to the provisions of land reform with present situation. Because the number and needs of the population and the development of technology, transportation and social economy is different from the situation in the 1960s. The maximum extent of non-agricultural land tenure as intended by Article 17 and Law Number 56 of 1960 stipulated by the government shall be timed to receive clear attention and regulation. It is done is to implement the sovereignty of the people where people have sovereignty to get equal treatment and rights in the field of land for the welfare of his life.

\section{Conclusions}

The Agrarian Reform aims to create an agrarian-based resources for the welfare of the people in order to organize the life of a more just society to improve the sustainability of the Indonesian national and statehood system and to promote community harmony. The objectives of the Agrarian Reform are to reduce poverty, create jobs, improve people's access to economic resources especially land, rearrange the inequality of ownership, use and utilization of land and agrarian resources, reduce disputes and conflicts over land and agriculture, improve and maintain quality of the environment, increasing food security and community energy. The objective of land reform in Indonesia is to enhance the income and living standards of the tiller peasants, as a basis or prerequisite for organizing economic development towards a just and prosperous society based on Pancasila. To achieve the intended objectives is done by holding a fair share of the peasants' livelihoods in the form of land and fair share of results as well, implementing land tenure for peasants, ending the landlord system, and protecting the weak economy community.

The main obstacle to the implementation of land conversion is the pattern of the current government's political policies that are pursuing economic growth and there is a view among bureaucrats that land conversion is a "taboo" program to be discussed, moreover to be implemented because it is considered a communist product, the concept of land for peasants is a communist concept.

\section{References}

1. B. Harsono, Hukum agraria indonesia sejarah pembentukan UUPA, isidan pelaksanaannya, p. 47 (Penerbit Djambatan, Jakarta, 2007)

2. A.P. Parlindungan, Komentar atas undang-undang pokok agraria, p. 68(Alumni, Bandung, 1998)

3. A. Surono, Fungsi sosial tanah, p. 2(Universitas Al-Azhar Indonesia, Jakarta, 2013)

4. U. Hasanah, Status kepemilikan tanah hasil konversi hak barat berdasarkan UU no. 5 tahun 1960 tentang peraturan dasar pokok-pokok Agraria dihubungkan dengan PP No. 24 tahun 1997 tentang pendaftaran tanah, Jurnal Ilmu Hukum, 3 (1), (2013)

5. A. Raharjo, Pendaftaran konversi tanah hak milik adat oleh ahli waris, Tesis, p. 14 (Universitas Diponegoro, Semarang, 2010) 
6. P. Mahmud Marzuki, Penelitian hukum, p. 52 (Kencana Prenada Media Group, Jakarta, 2009)

7. J. Bentham, An introduction to the principles of morals and legislation, p. 6-7 (Batoche Books, Kitchener, 2000)

8. H. Burns, Happiness and utility: Jeremy Bentham's equation, Journal Utilitas, 17 (1),p. 43(2005)

9. P. Schofield, Utility and democracy: the Political thought of Jeremy Bentham, p. 28-29 (Oxford University Press Inc, New York, 2006)

10. Mudjiono, Hukum agraria, p. 42-43 (Liberty, Yogyakarta, 1992)

11. Mudjiono, Hukum agraria, p. 50 (Liberty, Yogyakarta, 1992) 